\title{
Inside the Research-Assemblage: New Materialism and the Micropolitics of Social Inquiry
}

\author{
by Nick J. Fox and Pam Alldred \\ University of Sheffield; Brunel University
}

Sociological Research Online, 20 (2), 6

$<$ http://www.socresonline.org.uk/20/2/6.html>

DOI: $10.5153 /$ sro.3578

Received: 16 Sep 2014 | Accepted: 4 Feb 2015 I Published: 31 May 2015

\begin{abstract}
This paper explores social inquiry in terms of the 'research-assemblages' that produce knowledge from events. We use the precepts of new materialism (and specifically DeleuzoGuattarian assemblage ontology) to develop understanding of what happens when social events are researched. From this perspective, research is not at root an enterprise undertaken by human actors, but a machine-like assemblage of things, people, ideas, social collectivities and institutions. During social inquiry, the affect economies of an eventassemblage and a research-assemblage hybridise, generating a third assemblage with its own affective flow. This model of the research-assemblage reveals a micropolitics of social research that suggests a means to interrogate and effectively reverse-engineer different social research methodologies and methods, to analyse what they do, how they work and their micropolitical effects. It also suggests a means to forward-engineer research methods and designs to manipulate the kinds of knowledge produced when events are researched.
\end{abstract}

\section{Keywords: Research Methodology, New Materialism, Ontology, Assemblage, Affect, Deleuze and Guattari}

\section{Introduction: New materialism and the ontology of the social}

This paper explores social inquiry in terms of 'new materialist' ontology, and the 'research-assemblages' that produce knowledge from events during social inquiry. Our objectives are first, to establish the ontological precepts underpinning new materialism; second, to use these precepts to fully explore the implications of new materialist ontology for the kinds of knowledge that social research can produce; and third, to consider the opportunities afforded by a new materialist analysis of social inquiry for devising methods and designs whose effects on knowledge production can be both fully recognised and strategically manipulated.

Social scientific assessments of how knowledge can be generated by social inquiry turn ultimately upon the ontology that links events, researchers and research tools (Danermark et al. 2002: 18, Stanley and Wise 1993: 14).[1] Differing understandings of these ontological inter-relationships are then reflected within epistemological stances (Morgan 2007: 52): often broadly defined as realism and constructionism (Alvesson and Skoldberg 2009, Barad 1996: 162-163), with practical implications for social research methodology and methods. Proponents of realist positions aspire to a knowable reality independent of human concepts, while constructionists argue - to greater or lesser extents - that what may be known is limited to the constructions of reality produced within specific social and cultural contexts. Efforts continue to try to find resolution or common ground between realist and constructionist positions (see for example, Lau and Morgan 2014; Thibodeaux 2014), as these foundational questions about reality affect what can be said about the social world, and define the relationship between researcher and researched, and the status of data gathered in empirical studies. 
mediate between these epistemological disputes, offers an alternative ontology that - according to its advocates - 'cuts across' or is 'transversal to' the realist/constructionist dualism (Barad 1996: 165; van der Tuin and Dolphijn 2010: 157). This is achieved by displacing the human researcher/observer from her/his central position (and hence as key arbiter) in the interaction between the world of events and the processes of research. In this new materialist ontology, the capacity of research to engage with events no longer revolves around the disputed capacity of a human observer either to uncover the real mechanisms that produce the social or natural world (the realist position), or to offer contextual understandings of it (the constructionist stance). Instead, as will be seen, both events and research processes are considered as material, relational and interacting networks comprising human and non-human components.

1.4 'New materialist' approaches have emerged from a variety of philosophical and social theoretical positions, including feminism, biophilosophy, actor-network theory, quantum mechanical theory and posthumanism (Ansell Pearson 1997; Barad 1996; Braidotti 2013; Grosz 1994; Latour 2005; Massumi 1996). Like constructionism, new materialist social theory has concerned itself with the material workings of power, but with a clear emphasis upon social production rather than social construction, and upon matter rather than textuality (Coole and Frost 2010: 7; Taylor and Ivinson 2013: 666). Like realists, new materialist theorists concern themselves with the contribution of science to social justice and liberation (Barad 1996: 164), but in materiality they see multiplicity, mutability and becoming rather than singularity, stability and being (Braidotti 2006: 200; Cheah 2010: 79).

1.5 Among the radical claims of new materialists are that materiality is relational and emergent, plural and complex, uneven and contingent (Coole and Frost 2010: 29); that nature and culture are not to be regarded as distinct realms - as both materially affect an ever-changing world (Barad 1996: 181; Braidotti 2013: 3; Haraway 1997: 209); and that the capacity for agency extends beyond human actors to the non-human and inanimate (Braidotti 2013, DeLanda 2006; Latour 2005).[2] Taken together, these distinctive features suggest that new materialism may offer novel opportunities to address the concerns of those involved in analysing social research data and applying it either to explain or to change the world: namely, the relationship between research data and the object of inquiry. We will explore what a new materialist social ontology reveals about the processes and micropolitics of social inquiry, about the relationships between events, research and knowledge, and the kinds of knowledge that different research designs (methodologies) and methods can produce.

Our point of entry into an exploration of social inquiry from within new materialist ontology is by considering research as assemblage, a concept that we will examine shortly. From a new materialist perspective, a research-assemblage (Coleman and Ringrose 2013: 17; Fox and Alldred 2013: 784; Ringrose and Renold 2014: 774) will comprise the bodies, things and abstractions that get caught up in social inquiry, including the events that are studied, and the researchers. But if research can be assembled it can also be dis-assembled, and this paper will delve inside the research-assemblage, opening up the research process to micro-political investigation, revealing the material interactions between researcher and researched. We will use this mode of analysis to explore a range of quantitative and qualitative research methods and methodologies, to assess the processes that go on within their different research-assemblages, and the micropolitics they produce. From this we will reflect upon how a materialist ontology can inform the design of social inquiry methodologies, raising the possibility of engineering research methods and methodologies by designing into them specific micropolitical objectives. Before this, for the benefit of readers unfamiliar with a new materialist perspective, we summarise the framework upon which this ontology is built.

\section{New materialist ontology and social inquiry}

2.1 Though materialism was a significant element of early sociology (Shalin 1990) the 'new' materialisms that have emerged recently within the social sciences and humanities are discontinuous with that earlier tradition. In part, the current 'turn to matter' has been informed by post-structuralist, feminist, post-colonialist and queer theories, which rejected economic and structuralist determinism as inadequate satisfactorily to critique patriarchy, rationalism, science and modernism, or to supply a critical and radical stance to underpin struggles for social justice and plurality (Braidotti 2006: 24-25; Game 1991: 12). Other strands within new materialism include actornetwork theory, artificial intelligence, biophilosophy, evolutionary theory, Foucauldian genealogy, neuroscience, philosophical posthumanism, quantum physics and Spinozist monism (Ansell Pearson 1997; Barad 1996; Best 1995; Braidotti 2006, 2013; Clough 2008; Coole and Frost 2010; Connolly 2011; Grosz 1994; Haraway 1991; Latour 2005; Massumi 1996). 
micro/macro distinctions, and recognising that materiality and the world and human history are produced by a range of material forces that include physical, biological, psychological, social and cultural (Barad 1996: 181; Braidotti 2013: 3). By drawing nature and culture, mind and matter into a single arena, new materialisms radically extend the scope of materialist analysis beyond traditional concerns with structural and 'macro' level social phenomena (van der Tuin and Dolphijn 2010. 159), to address issues often regarded as 'micro-sociological', because of their association with how thoughts, desires, feelings and abstract concepts contribute to social production (Braidotti 2000: 159; DeLanda 2006; 5). These elisions also mean that new materialism cuts across other social theory dualisms including structure/agency, reason/emotion, human/non-human, animate/inanimate (Braidotti 2013: 4-5; Coole and Frost 2010: 26-27; van der Tuin and Dolphijn 2010. 157). Consequently, new materialism 'foregrounds an appreciation of just what it means to exist as a material individual with biological needs yet inhabiting a world of natural and artificial objects, well-honed micro-powers of governmentality, but no less compelling effects of international economic structures' (Coole and Frost 2010: 28).

Beyond these commonalities, new materialist scholars have diverged in how they have conceptualised materialist ontology. Thus, for example, Barad (1996: 181) retains a concept of agency but extends it beyond human actors to the non-human and non-animate; actor-network theory (ANT) scholars speak of human and nonhuman 'actants' that have in common a capacity for agency within a heterogeneous network comprising both natural and cultural elements (Latour 2005: 54; Law 1992: 380); while Deleuze, Guattari and their followers prefer to talk of affectivity (Deleuze 1988: 101; Massumi 1996). Barad (1996: 188) describes the 'intra-actions' between matter and knowledge that produce phenomena, while Deleuze and Guattari (1988: 88), DeLanda (2006) and Latour (2005) consider how the physical and cultural assemble together to produce bodies, social formations and events. To achieve the objective of this paper to draw out features of new materialism that impact upon the ontology of social inquiry, we will use the well-developed and widely-applied conceptual framework deriving from Gilles Deleuze's (1988) reading of Spinoza, as developed and applied in the work of Deleuze and Guattari (1984, 1988), by theorists such as Braidotti (2006), DeLanda (2006), Grosz (1994) and Thrift (2004), and by social researchers such as Fox and Alldred (2013), Renold and Ringrose (2011) and Youdell and Armstrong (2011), though we cross reference to other new materialist scholars where appropriate.

2.4 The DeleuzoGuattarian approach is predicated upon three propositions. Firstly, bodies and other material, social and abstract entities should be regarded not as ontologically-prior essences occupying distinct and delimited spaces, but as relational, gaining ontological status and integrity only through their relationship to other similarly contingent and ephemeral bodies, things and ideas (Deleuze 1988: 123; Haraway 1991: 201). Assemblages (Deleuze and Guattari 1988: 88) of these relations develop in unpredictable ways around actions and events, 'in a kind of chaotic network of habitual and non-habitual connections, always in flux, always reassembling in different ways' (Potts 2004: 19), and work like 'machines' (Deleuze and Guattari 1988: 4) that do something, produce something. An important opportunity afforded by this understanding is that whatever is assembled can be disassembled (Harman 2013: 119) to see how it works, a characteristic we will exploit fully in this paper.

2.5 Second, all matter has an 'agential' capacity to affect, rather than being inert clay moulded by human agency, consciousness and imagination (Barad 1996: 181; Coole and Frost 2010: 2). Consequently, the ontology replaces a conventional conception of agency with the Spinozist notion of affect (Deleuze 1988: 101), meaning simply the capacity to affect or be affected: in an assemblage, there is no 'subject' and no 'object' (Anderson 2010: 736). Rather, an affect is a 'becoming' (Deleuze and Guattari 1988: 256) that represents a change of state or capacities of an entity (Massumi 1988: xvi) - this change may be physical, psychological, emotional or social. Affects produce further affective capacities within assemblages (Deleuze and Guattari 1988: 400), and because one affect can produce more than one capacity, social production is 'rhizomic' (ibid: 7) rather than linear: a branching, reversing, coalescing and rupturing flow.

2.6 Affective flows render assemblages constantly in flux, with territorialising flows stabilising an assemblage, while others de-stabilise or de-territorialise it (Deleuze and Guattari 1988: 88-89), fragmenting an assemblage. Affects may also aggregate relations in assemblages, while other affects are non-aggregative or 'singular', affecting a single relation within an assemblage in a unique way. So, for example, naming a new pet kitten 'Daisy' is a singular affect, while categorising it as tabby or tortoiseshell is aggregative. ${ }^{[3]}$ These fluxes within and between assemblages create an 'economy' of affects (Clough 2004: 15) and are the process by which lives, societies and history unfold, 'in a world which is constantly becoming' (Thrift 2004: 61).

2.7 The final proposition marks the radical divergence from the exclusive focus in earlier materialist sociologies upon macro-structures, social institutions and economic relations noted earlier. Because thoughts, 
ideas, feelings, desires, and collective abstractions and 'constructions' can all materially affect and be affected by other relations in an assemblage, they can be treated in exactly the same way as other (seemingly 'more material') relations (Deleuze and Guattari 1988: 89; see also Barad 1996: 181). With this focus upon the materiality of affects and of the actions, interactions, subjectivities and thoughts they produce, the net is cast far more widely than in earlier materialisms (Coole and Frost 2010: 26), to address materiality across 'micro/macro' and culture/nature divides.

\section{The research-assemblage: affects, flows and micropolitics}

3.1 These concepts - of assemblages, affective flows and economies, territorialisations and aggregations, provide the means for us to launch our new materialist (henceforth, for conciseness, 'materialist') analysis of social research. Conventionally, social inquiry (like other scientific inquiry) has been anthropocentric, regarding the researcher as the prime mover in the research enterprise, whose reason, logic, theory and scientific methodologies gradually impose order upon 'data' to supply an understanding, however imperfect, of the world (and its social construction). By contrast, a materialist ontology of assemblages and affects treats the researcher and the researched event, plus the many other relations involved in social inquiry such as the tools, technologies and theories of scientific research, as elements in a research-assemblage productive of a variety of material capabilities in its human and non-human relations. We take this concept of the research-assemblage as our focus for what follows.

3.2 Deleuze and Guattari (1988:4) described assemblages as 'machines' that link affects together to produce or do something. With this in mind, a 'research-assemblage' can be defined in terms of the multiplicity of affective relations in the research process, including the 'events' to be researched (these can be any instance of bodies, things, settings or social formations, or of assemblages of these); research tools such as questionnaires, interview schedules or other apparatus; recording and analysis technologies, computer software and hardware; theoretical frameworks and hypotheses; research literatures and findings from earlier studies; the 'data' generated by these methodologies, methods and techniques; and of course, researchers. To this list may be added contextual relations such as the physical spaces and establishments where research takes place; the frameworks, philosophies, cultures and traditions that surround scientific research; ethical principles and ethics committees; research assessment exercises; and all the paraphernalia of academic research outputs: libraries, journals, editors, peer reviewers and readers.

3.3 While it is thus possible to disassemble a research-assemblage to disclose its constituent relations, it is far more productive for our analysis to seek out the affects that bind the assemblage together, and we will use Deleuze and Guattari's machine metaphor as the basis for our analysis. To this end, we will treat the research process as if it were a series of interconnected machines that do specified tasks such as data collection, data analysis and so forth (Fox and Alldred 2014; Jackson and Mazzei 2013). Like physical machines that have been constructed to work in a specified way and produce certain outputs, we will regard the relations within a research-assemblage as engineered to achieve their objectives as a consequence of the particular affective flows between event, instruments and researchers that a methodology or method requires. Thus, a 'data collection machine' would take aspects of an event as its raw materials, and by the means specific to its design, generates 'data'. An analysis machine processes data according to specific rules of logic, deduction or inference, and frequently interprets it within a specific theoretical or conceptual framework to produce 'findings' in the form of generalities or summaries. A reporting machine takes these outputs of data analysis and creates knowledge products for dissemination: theory, policy and practice implications and so forth. $\left.{ }^{4]}\right]$

3.4 Thinking about the affects in these research machines reveals a further interesting aspect of their constitution. Unlike 'spontaneous' assemblages in daily life (for instance, a 'sexuality-assemblage' (Fox and Alldred 2013) comprising bodies and body-parts, social institutions, places, clothing and other body adornments, values, scripts and norms), research machines comprise few relations and affects, making them readily amenable to reverse engineering in order to understand how they work. To offer a simple example: a sampling frame can be unpicked to reveal a machine that works by means of a single affect targeted at the various events available to social inquiry. This affect sorts events to be included in a study (for instance, teenagers) from those to be excluded (those under 13 or over 19). In other research machines, the affects may be more complex: a summary statistic such as chi-squared comprises a series of arithmetic operations (affects) that transform 'data' into a single indicator of statistical significance. This means that by unpicking research machines, it will be possible to assess how a change of data collection or analysis method, or of design (for instance, from survey to ethnography) alters the affective flow in the research-assemblage, and hence what kind of 'knowledge' it produces (Jackson and Mazzei 2013: 263). (It also means the affects in research machines can be 'reengineered' to make them perform differently, a key point discussed later in the paper.) 
However the materialist ontology of social inquiry we are pursuing here allows us to push this analysis of the research-assemblage and its constituent machines a step further. Identifying the affects in the researchassemblage opens to scrutiny the micropolitics inherent in the research machines that do data collection, data analysis and so on. These in turn allow us to explore the micropolitics of the research process, of what happens when events are transformed into 'data', and who gains and who loses in the process (Gillies and Alldred 2012: 56). To give an example, in a randomised trial, controlling the experimental conditions and use of statistical techniques together limit the affective capacities of 'confounding' relations found in 'real-world' settings, empowering a researcher to model the 'uncontaminated' affect of an 'independent' upon a 'dependent' variable. By contrast, in qualitative studies a 'naturalistic' approach limits the researcher affective capacities, while enhancing the affectivity of respondents' accounts. The micropolitics of these research-assemblages differ because of the affects that hold them together, and what they do to the relations in the assemblage.

3.6 Later in the paper, we will reverse-engineer methodologies and methods in just this way, to understand how they work and what their micropolitics tell us about different research approaches. In order to achieve that objective, it will be helpful to set out a more general appraisal of how a research-assemblage works, based on the materialist analysis of relations, affects and micropolitical movements in research-assemblages discussed earlier.

\section{A model of research micropolitics}

4.1 To develop from within the materialist perspective a model of what happens when an event - for instance, the school trip described by Youdell and Armstrong (2011: 146) - is researched sociologically, let us consider the event as an assemblage ' $E$ 'comprising a set of relations 'ABC' (in this example, the teachers and students, the visit location and the route traversed, the picnic lunch, the educational objectives and so forth), linked by affects that make this event do whatever it does. The aim of a research study will be to apply designs and methods that can somehow identify the $\mathrm{ABC}$ relations within the $E$ assemblage, explore the affects between these relations, and from this offer an explanation of what $E$ does within its particular social context.

However, as we have noted, a research study must also be considered both as an event in its own right, and as an assemblage $R$. $R$ will have its own set of relations 'XYZ', which are all the paraphernalia of academic inquiry such as the researcher, methodologies, research instruments, theories and so on. As was discussed earlier, these $X Y Z$ relations have been purposively assembled in order to engineer specific affective flows within the research-assemblage, with the objective of taking the event-assemblage $E$ or other similar events, and producing a textual or other output that will form the research 'knowledge' of $E$. Most critically for this model of research, if $R$ is to document, analyse and eventually turn $E$ into knowledge, this requires that the researchassemblage must also be capable of being affected by the affects between relations $A B C$ in the event being studied. (This capacity to be affected is described variously in conventional social research texts, for instance as the sensitivity and specificity that an instrument such as thermometer or a questionnaire needs in order for it to be useful as a measure, or of the hermeneutic understanding ('verstehen') in a qualitative study that enables a researcher to make sense of an event being studied.)

4.3 For the sake of precision, it should be considered that when $E$ becomes the subject of the research assemblage $R$, the consequent interaction between affects in $E$ and $R$ produces a third, hybrid assemblage, which we will designate $R / E$, with its own affect economy that links relations $A, B, C, X, Y$ and $Z$. This economy will be distinct from those in either $E$ or $R$, though it is the affects in $R$ that will actually produce the research outputs, 'knowledge' of the $E$ assemblage, or the altered sensibilities in the researcher and the research's audience that a constructionist would describe as 'social constructions' of $E$. It may also produce effects on $E$ itself, such as changes in behaviour due to a 'Hawthorne' effect from being observed, increased individual or collective reflexivity, or impacts on the event (for instance, a custom or tradition) due to attention from outsiders.

4.4 This way of understanding the possible interactions between the affect economies of $E$ and $R$ within a hybrid $R / E$ assemblage enables a sophisticated understanding of the micropolitics of social research. This can be apprehended by considering two opposing 'hazards' often discussed in social research. The first of these occurs when the 'research' relations XYZ within R/E dominate the flow, asserting a powerful effect over the relations $A B C$ of the event-assemblage $E$. This may happen for various reasons: for instance when a sampling strategy intentionally excludes key aspects of $E$; by controlling out naturalistic contexts; by imposing a theoretical framework on data; by use of statistics to summarise or generalise; or by textual (mis)representation of $E$. In such cases, $R$ affects radically re-territorialise the affective flow between $\mathrm{ABC}$ relations, to the extent that the 
'knowledge' produced by $R / E$ no longer reflects the flow within $E$, distorting its representation in research outputs. This is the situation posited by radical social constructionists, who have argued that modernist research has constructed rather than described its objects (for example in Foucault's (1981) and Kitzinger's (1987) studies of sexuality).

The opposing hazard occurs when the $X Y Z$ relations in the research-assemblage have so little affective capacity that the $A B C$ relations are dominant within the $R / E$ assemblage. Now the research process becomes a machine whose outputs are trivial or anodyne rather than analytical; descriptive or journalistic rather than critical. This may occur when affects in the research-assemblage are weak, for instance if the research design lacks a powerful (affective) analytical machine or is theoretically uninformed; the research instruments do not possess the capacity to differentiate the relations or affects in the event; or the reporting is literal rather than critical. Occasionally, of course, this affective weakness is seen as an opportunity, for example in case studies that set out to describe specific events; or in 'Delphi' methodologies that aim to gain consensus among experts and thereby offer a definitive statement on current knowledge (for example, a study that draws on a wide range of expert opinions in order to assess the current status of scientific consensus concerning the effects of the human species upon global climate).

However, between these extremes there will be many research situations when neither ABC nor XYZ affects overwhelmingly control the affective flow in the $R / E$ assemblage. Yet in each and every situation, there will be a dynamic tension between the affective flow of $E$ and that of $R$, a tension that has consequences for the knowledge and representations of the social world that research produces, and potentially for the social world itself. Applying this materialist analysis supplies a means to explore the micropolitics of the research process, understood in terms of affective interactions between event, research methodologies/methods and researcher.

\section{Dis-assembling the research-assemblage}

5.1 In the remainder of the paper, we will use this materialist understanding of the $R / E$ assemblage to explore in greater detail a range of research machines, their affect economies and the micropolitics of social inquiry these machines produce. The utility and validity of many of these research-assemblages and machines are contested within contemporary social inquiry, but rather than debating the traditional critiques, we have applied our model of research-as-assemblage to make sense of what these designs and methods actually do, and how they work. First we asked what a machine is designed to do, and what outputs it produces. From this, we applied a more critical assessment, imposing the materialist ontology of assemblages and affects to reverse engineer the machine and disclose the affective flows that make it work. We examined how the design of the machine enhances certain affective flows and mitigates or closes down others. This is the affect economy (Clough 2004: 15) of the machine, which enables it to work in a specific way, and which (as was discussed in the previous section) produces the micropolitics of its interactions with the affect economy of the event studied, with consequences for the knowledge produced, the researchers and the events themselves. ${ }^{[5]}$

5.2 To clarify this analysis, we will apply (without specific critiques) this approach of reverse engineering or disassembling research machines to three methods or techniques (sampling, the questionnaire, and thematic qualitative analysis) and then two research methodologies often used in social inquiry: the survey and the qualitative interview. This analysis will supply the basis for a more critical subsequent discussion of how social inquiry is viewed from a materialist perspective. Analysis of many of the other techniques, methods and methodologies used in social research are then presented in Tables 1 and 2.

\section{Techniques and Methods}

\section{Sampling}

5.3 A sampling machine performs a relatively simple task within a research-assemblage, selecting events (respondents, institutions, occurrences) for inclusion in or exclusion from a study, based upon two sequential affects. The first affect sets the choice of sampling approach (for example, representative sample, stratified sample, convenience sample, theoretical sample) for the researcher to implement; the second affect includes or excludes specific events, applying the appropriate means of selection (random inclusion for a representative sample; purposive inclusion across a range of events for a theoretical sample, and so forth), as set by the first affect. The affect economy in this machine acts upon study events, systematically including some in the sample and excluding others. Micropolitically, this economy empowers a researcher to achieve the impossible (to assess an entire population), by restricting the affects from the event population entering the research assemblage according to specific, though arbitrary principles. 


\section{The Questionnaire}

The questionnaire is actually two separate machines: one for questionnaire construction, the other for its administration. The affect in the first transforms variables to be measured (for example, political belief) into a question that will serve as an indicator (for example: how did you vote at the last election?), sometimes with preselected permissible responses. The affects in the second act on researcher and respondents, requiring a question to be asked, an answer to be supplied, this answer to be recorded and possibly allocated to a precoded category, and the instrument to be applied consecutively and independently to each respondent in turn, generating completed questionnaires ready to be fed into an analysis machine. The affective economy of this machine extracts information systematically from respondents to produce a dataset. Micropolitically, the machine acts as a filter on the affect economies of events being studied, extracting only certain data, and categorising them according to the affect economy of the instrument rather than that of the event itself.

\section{Thematic Qualitative Analysis}

5.5 Thematic analysis of qualitative data is a machine that (manually, or with software assistance) organises and reduces non-numerical data, making it more manageable and amenable to systematic reporting. It entails two affects: a pre-analysis code-generation affect that allocates a code to a range of similar textual occurrences (for instance, to pieces of text that in some ways reference family finances); and an aggregative affect that takes each piece of data in turn and codes it according to this scheme.[6] The affect economy here acts on raw data from a study to aggregate it, reduce variability, and open it to reporting. The micropolitics of the machine is to reduce complexity in data and aggregate together disparate aspects of an event in ways defined by the analyst (for instance, in terms of a conceptual or theoretical framework).

\section{Research Methodologies}

5.6 We now consider two common research designs, looking at each as a whole but also as constituted from a number of machines, including those described in the previous thumb-nail sketches and those listed in Table 1.

\section{The Survey}

5.7 The survey is a social research design assemblage that typically produces a quantitative summary of specific aspects of a study population, as defined by a research question. This is done by a series of researchmachines that a) draw a representative or stratified sample from a population; b) use methods such as questionnaires to gather data on specified measures or indicators (often forcing responses into pre-specified categories); c) submit these to descriptive or inferential statistical analysis; and d) report a summary of the sample's features, often with an assessment of confidence to generalise these to a population.

5.8 The affect economy that makes the survey design work derives from the economies of its constituent machines. Affects in the sampling machine supply a means to allocate events to the sample; those in the questionnaire machine select and categorise those features of events to be studied and record them in a form amenable to quantitative analysis; affects in the statistical analysis machine aggregate and manipulate the data mathematically, reducing it to summary values and statistical assessments of probability that efface the complexities and divergences in the events; the affects of the result-writing machine use these aggregated and de-contextualised findings and present them in an effort to answer the study's research questions.

5.9 Micropolitically, all these machines are highly aggregative: as sampling and questionnaire machines systematise research selection and data collection, they restrict which affects from the event can become part of the $R / E$ assemblage; the analysis machine aggregates the affective capacities of the event into numerical metrics, simplifying and thereby reducing the granularity of the event-affects represented in the research outputs; the writing machine imposes the constraints of a narrow research question on the affects in the event. In these ways, a survey powerfully privileges a researcher perspective over the events it studies.

\section{The Qualitative Interview}

5.10 Here we examine qualitative interviewing as a research methodology designed to provide 'rich descriptions' of a social event or events by interrogating accounts elicited from social actors. Within this researchassemblage are a number of machines that: a) set and refine the research question; b) select a sample - usually according to a purposive strategy to overcome the limitations of a relatively small sample size (Coyne 1997: 629); c) use individual or group interviews (based on an interview schedule designed to inform the research question) to gain in-depth data on interviewees' affective backgrouud, engagement with the issues being studied, and reflections on these issues; d) undertake some kind of qualitative analysis, typically one that categorises data 
into themes either 'grounded' in the data or deriving from a pre-defined theoretical or conceptual framework, or imposes some other structure upon the data; and e) report these data in a textual format that often includes extracts from the interviews conducted.

5.11 The affect economy of this methodology is again provided by its constituent machines. The purposive sampling machine selects subjects to interview based on expectations of their affective economies, and often aims to maximise diversity rather than to ensure data is representative of a wider population. An interview schedule is a simple affect that determines which elements of the subjects' affective engagements with the topic can be reported, while the question/answer format underpinning the interview method also governs the material gathered. The qualitative analysis machine (as described earlier) organises, aggregates and reduces the textual material, enabling themes to be developed or explanatory constructs to be developed; writing produces a second-order account of the events being studied, as interpreted first by interviewees and then by the researcher, and illustrates the account with 'representative' or 'allusive' quotations from the interviewees.

5.12 The micropolitics of qualitative interviewing reflect the interactions between researcher, interviewees and the events they describe. The researcher's questioning role and the answering role of subjects produce inequality, while the choice of research question, sampling and interview schedule machines all impose a framework on the affects admitted into the $R / E$ assemblage. However, the interview format does enable respondents to control the accounts they offer, and researchers may actively try to hand some power back to interviewees, to 'give them a voice'. As noted earlier, the systematising and aggregating affects in the thematic analysis machine privilege the analyst's account over those of respondents; this is reflected in how the data are reported - typically within an imposed structure that establishes the researcher's unitary account of the event, with interviewees' accounts used selectively to justify the researcher's answer to the research question.

5.13 These detailed descriptions of methods and designs demonstrate how we have moved from what a machine does, to how its affects make it work, and finally what this means for the micropolitics of the hybrid $R / E$ assemblage. Tables 1 and 2 summarise other methods, techniques and designs that may be reverse engineered in the same way. The first table is divided into research techniques, data collection and data analysis methods, and aspects of data presentation. Table 2 analyses the principal research designs from across the spectrum of social inquiry. Of course, social research is continually innovating new designs and methods, often highly antagonistic to positivistic science, and these too are amenable to analysis, to reveal their unique affect economies and micropolitics.

Table 1: Materialist assessment of social research methods and techniques

\section{A) Techniques}




\begin{tabular}{|c|c|c|c|}
\hline & $\begin{array}{l}\text { Summary of what } \\
\text { the machine } \\
\text { produces: }\end{array}$ & $\begin{array}{l}\text { Affective flow in the } \\
\text { machine: }\end{array}$ & $\begin{array}{l}\text { Micropolitics of the } \\
R / E \text { assemblage: }\end{array}$ \\
\hline $\begin{array}{l}\text { Setting/refining a } \\
\text { Rsearch Question }\end{array}$ & $\begin{array}{l}\text { A delimited and } \\
\text { therefore answerable } \\
\text { research question. }\end{array}$ & $\begin{array}{l}\text { Defines what is to be } \\
\text { studied. }\end{array}$ & $\begin{array}{l}\text { Asserts researcher's } \\
\text { choice of which event } \\
\text { affects are studied. }\end{array}$ \\
\hline $\begin{array}{l}\text { Internal Study } \\
\text { validity }\end{array}$ & $\begin{array}{l}\text { Data that is relevant to } \\
\text { the research question. }\end{array}$ & $\begin{array}{l}\text { Selects the data to be } \\
\text { gathered and analysed. }\end{array}$ & $\begin{array}{l}\text { Justifies the machines } \\
\text { selected for the } \\
\text { research-assemblage. }\end{array}$ \\
\hline $\begin{array}{l}\text { External Study } \\
\text { Validity }\end{array}$ & $\begin{array}{l}\text { Data that is } \\
\text { representative of the } \\
\text { population. }\end{array}$ & $\begin{array}{l}\text { Establishes rules for } \\
\text { choice of events from } \\
\text { a population. }\end{array}$ & $\begin{array}{l}\text { Justifies inferences } \\
\text { researchers make from } \\
\text { findings. }\end{array}$ \\
\hline $\begin{array}{l}\text { Instrument } \\
\text { Reliability }\end{array}$ & $\begin{array}{l}\text { Data that is consistent } \\
\text { and avoids random } \\
\text { errors. }\end{array}$ & $\begin{array}{l}\text { Quality assures tools } \\
\text { used to measure an } \\
\text { event. }\end{array}$ & $\begin{array}{l}\text { Controls quality of } \\
\text { tools and researcher } \\
\text { conduct. }\end{array}$ \\
\hline $\begin{array}{l}\text { Instrument } \\
\text { validity }\end{array}$ & $\begin{array}{l}\text { Data that is accurate } \\
\text { and avoids systematic } \\
\text { errors. }\end{array}$ & $\begin{array}{l}\text { Assesses instrument } \\
\text { accuracy against a } \\
\text { defined standard. }\end{array}$ & $\begin{array}{l}\text { Assures the "truth' of } \\
\text { data from research } \\
\text { tools/interpretations. }\end{array}$ \\
\hline Ethics Approval & $\begin{array}{l}\text { A study that meets } \\
\text { cultural expectations } \\
\text { for research conduct. }\end{array}$ & $\begin{array}{l}\text { Assesses research } \\
\text { against cultural } \\
\text { principles and rules. }\end{array}$ & $\begin{array}{l}\text { Justifies affects of } \\
\text { researcher upon } \\
\text { researched events. }\end{array}$ \\
\hline $\begin{array}{l}\text { Representative } \\
\text { Sample }\end{array}$ & $\begin{array}{l}\text { Equivalence between } \\
\text { sample and } \\
\text { population. }\end{array}$ & $\begin{array}{l}\text { Determines which } \\
\text { events are selected for } \\
\text { study. }\end{array}$ & $\begin{array}{l}\text { Justifies how events } \\
\text { are included in the } R / E \\
\text { assemblage. }\end{array}$ \\
\hline $\begin{array}{l}\text { Convenience } \\
\text { Sample }\end{array}$ & $\begin{array}{l}\text { Provides sufficient } \\
\text { events to be studied. }\end{array}$ & $\begin{array}{l}\text { Sets arbitrary cut-off } \\
\text { point for recruiting } \\
\text { events. }\end{array}$ & $\begin{array}{l}\text { Justifies how many } \\
\text { events are included in } \\
\text { the } R / E \text { assemblage. }\end{array}$ \\
\hline $\begin{array}{l}\text { Theoretical } \\
\text { Sample }\end{array}$ & $\begin{array}{l}\text { Sample that reflects } \\
\text { the breadth of affects } \\
\text { in a population. }\end{array}$ & $\begin{array}{l}\text { Applies an conceptual } \\
\text { framework for } \\
\text { including events. }\end{array}$ & $\begin{array}{l}\text { Justifies which events } \\
\text { are included in the } R / E \\
\text { assemblage. }\end{array}$ \\
\hline
\end{tabular}

B) Data Collection Methods 


\begin{tabular}{|l|l|l|l|}
\hline $\begin{array}{l}\text { Individual } \\
\text { Interview }\end{array}$ & $\begin{array}{l}\text { Accounts of events } \\
\text { supplied by human } \\
\text { subjects. }\end{array}$ & $\begin{array}{l}\text { Elicits accounts } \\
\text { relevant to the } \\
\text { research question. }\end{array}$ & $\begin{array}{l}\text { Privileges human } \\
\text { interpretations of event } \\
\text { affects. }\end{array}$ \\
\hline Group Interview & $\begin{array}{l}\text { Interactive accounts of } \\
\text { events supplied by } \\
\text { human subjects. }\end{array}$ & $\begin{array}{l}\text { Elicits interactive } \\
\text { accounts relevant to } \\
\text { the research question. }\end{array}$ & $\begin{array}{l}\text { Privileges human } \\
\text { interpretations of event } \\
\text { affects. }\end{array}$ \\
\hline Observation & $\begin{array}{l}\text { Descriptions of events } \\
\text { by a researcher. }\end{array}$ & $\begin{array}{l}\text { Establishes researcher } \\
\text { as data collection } \\
\text { instrument. }\end{array}$ & $\begin{array}{l}\text { Privileges researcher's } \\
\text { perspective and } \\
\text { analysis of events. }\end{array}$ \\
\hline Questionnaire & $\begin{array}{l}\text { Study sample scores } \\
\text { on multiple measures. }\end{array}$ & $\begin{array}{l}\text { Gathers and collates } \\
\text { data on pre-selected } \\
\text { indicators. }\end{array}$ & $\begin{array}{l}\text { Imposes researcher } \\
\text { categories and } \\
\text { measures on event } \\
\text { affects. }\end{array}$ \\
\hline Experiment & $\begin{array}{l}\text { Effect of a defined } \\
\text { affect within an event. }\end{array}$ & $\begin{array}{l}\text { Tests affect(s) in an } \\
\text { controlled setting. }\end{array}$ & $\begin{array}{l}\text { Imposes limits on } \\
\text { which affects enter the } \\
R / E \text { assemblage. }\end{array}$ \\
\hline
\end{tabular}

C) Analytical Methods 


\begin{tabular}{|l|l|l|l|}
\hline Anatistical & $\begin{array}{l}\text { Numerical indicator of } \\
\text { a study sample } \\
\text { characteristics. }\end{array}$ & $\begin{array}{l}\text { Summarises data by } \\
\text { mathematical } \\
\text { formulae. }\end{array}$ & $\begin{array}{l}\text { Imposes statistical } \\
\text { models of populations } \\
\text { on data. }\end{array}$ \\
\hline $\begin{array}{l}\text { Thematic } \\
\text { Analysis }\end{array}$ & $\begin{array}{l}\text { Summary of data in } \\
\text { terms of pre-selected } \\
\text { themes. }\end{array}$ & $\begin{array}{l}\text { Categorises data in } \\
\text { terms of similarities in } \\
\text { attributes specified by } \\
\text { a conceptual or } \\
\text { theoretical framework. }\end{array}$ & $\begin{array}{l}\text { Imposes researcher's } \\
\text { categories on data. }\end{array}$ \\
\hline Grounded Theory & $\begin{array}{l}\text { Inductively-generated } \\
\text { theory to explain an } \\
\text { event }\end{array}$ & $\begin{array}{l}\text { Analyses event } \\
\text { assemblage to disclose } \\
\text { internal structure or } \\
\text { processes }\end{array}$ & $\begin{array}{l}\text { Privileges coherence } \\
\text { and structure in data } \\
\text { over divergence and } \\
\text { randomness }\end{array}$ \\
\hline Analysis & $\begin{array}{l}\text { Social or cultural } \\
\text { constructions and } \\
\text { power relations in } \\
\text { events. }\end{array}$ & $\begin{array}{l}\text { Reveals relations and } \\
\text { affects in linguistic } \\
\text { representations of } \\
\text { events. }\end{array}$ & $\begin{array}{l}\text { Establishes a } \\
\text { constructionist model } \\
\text { and privileges the } \\
\text { researcher's political } \\
\text { analysis. }\end{array}$ \\
\hline
\end{tabular}

D) Study Presentation 


\begin{tabular}{|l|l|l|l|}
\hline Writing up & $\begin{array}{l}\text { A report of the events } \\
\text { studied. }\end{array}$ & $\begin{array}{l}\text { Summarises and } \\
\text { explicates the data } \\
\text { collected and } \\
\text { analysed. }\end{array}$ & $\begin{array}{l}\text { Describes the event in } \\
\text { terms of the affects in } \\
\text { the R/E assemblage. }\end{array}$ \\
\hline Peer Review & $\begin{array}{l}\text { An assessment of } \\
\text { research output } \\
\text { quality }\end{array}$ & $\begin{array}{l}\text { Peers assess the } \\
\text { research output } \\
\text { against explicit or } \\
\text { implicit criteria. }\end{array}$ & $\begin{array}{l}\text { Incorporates the values } \\
\text { of the community of } \\
\text { researchers into the } \\
\text { R/E assemblage. }\end{array}$ \\
\hline Dissemination & $\begin{array}{l}\text { An audience for the } \\
\text { research report. }\end{array}$ & $\begin{array}{l}\text { Presents the research } \\
\text { report to selected } \\
\text { audiences. }\end{array}$ & $\begin{array}{l}\text { Uses the affective flow } \\
\text { of the R/E assemblage } \\
\text { to affect audiences. }\end{array}$ \\
\hline Policy & policy or practice. & $\begin{array}{l}\text { Applies the } \\
\text { conclusions of the } \\
\text { research to affect } \\
\text { policy or practice. }\end{array}$ & $\begin{array}{l}\text { Uses the affective flow } \\
\text { of the R/E assemblage } \\
\text { to affect policy or } \\
\text { practice. }\end{array}$ \\
\hline
\end{tabular}

Table 2: Materialist assessment of social research methodologies 


\begin{tabular}{|c|c|c|c|}
\hline & $\begin{array}{l}\text { Summary of what } \\
\text { the assemblage } \\
\text { produces: }\end{array}$ & $\begin{array}{l}\text { Affective flow in the } \\
\text { assemblage: }\end{array}$ & $\begin{array}{l}\text { Micropolitics of the } \\
R / E \text { assemblage: }\end{array}$ \\
\hline $\begin{array}{l}\text { Randomised } \\
\text { Controlled trial }\end{array}$ & $\begin{array}{l}\text { Truth or falsity of a } \\
\text { hypothesis about a } \\
\text { variable's effects. }\end{array}$ & $\begin{array}{l}\text { Discounts effects of } \\
\text { event affects other } \\
\text { than test affect. }\end{array}$ & $\begin{array}{l}\text { Justifies research } \\
\text { claims to describe } \\
\text { what a single event } \\
\text { affect does. }\end{array}$ \\
\hline Survey & $\begin{array}{l}\text { Descriptive statistics } \\
\text { on a population. }\end{array}$ & $\begin{array}{l}\text { Describes and } \\
\text { summarises specific } \\
\text { attributes of events. }\end{array}$ & $\begin{array}{l}\text { Justifies inferences } \\
\text { from sample data to a } \\
\text { population. }\end{array}$ \\
\hline $\begin{array}{l}\text { Qualitative } \\
\text { Interview }\end{array}$ & $\begin{array}{l}\text { Summary of accounts } \\
\text { concerning an event. }\end{array}$ & $\begin{array}{l}\text { Organises respondent } \\
\text { accounts of events. }\end{array}$ & $\begin{array}{l}\text { Privileges (double) } \\
\text { hermeneutic analysis } \\
\text { of one or more } \\
\text { events. }\end{array}$ \\
\hline Ethnography & $\begin{array}{l}\text { Detailed description } \\
\text { of events in a } \\
\text { specified setting. }\end{array}$ & $\begin{array}{l}\text { Presents } \\
\text { researcher/academic } \\
\text { assessment of a } \\
\text { setting. }\end{array}$ & $\begin{array}{l}\text { Privileges researcher } \\
\text { account and analysis } \\
\text { of an event. }\end{array}$ \\
\hline
\end{tabular}




\begin{tabular}{|l|l|l|l|} 
Ethnography & $\begin{array}{l}\text { Detailed description } \\
\text { of events in a } \\
\text { specified setting. }\end{array}$ & $\begin{array}{l}\text { Presents } \\
\text { researcher/academic } \\
\text { assessment of a } \\
\text { setting. }\end{array}$ & $\begin{array}{l}\text { Privileges researcher } \\
\text { account and analysis } \\
\text { of an event. }\end{array}$ \\
\hline $\begin{array}{l}\text { Mocumentary/ } \\
\text { Analysis }\end{array}$ & $\begin{array}{l}\text { Evaluation of an } \\
\text { event from } \\
\text { documentary sources } \\
\text { or artefacts. }\end{array}$ & $\begin{array}{l}\text { Organises and } \\
\text { interprets material } \\
\text { culture or documents. }\end{array}$ & $\begin{array}{l}\text { Imposes cultural } \\
\text { meanings on selected } \\
\text { cultural artefacts or } \\
\text { documents. }\end{array}$ \\
\hline Case Study & $\begin{array}{l}\text { Description of a } \\
\text { single event. }\end{array}$ & $\begin{array}{l}\text { Describes in detail } \\
\text { specific aspects of } \\
\text { one event. }\end{array}$ & $\begin{array}{l}\text { Claims to provide } \\
\text { full description of an } \\
\text { event. }\end{array}$ \\
\hline Delphi Study & $\begin{array}{l}\text { Consensus among } \\
\text { experts on a category } \\
\text { of events. }\end{array}$ & $\begin{array}{l}\text { Gathers and } \\
\text { synthesises opinions } \\
\text { to negotiate } \\
\text { agreement by } \\
\text { selected experts. }\end{array}$ & $\begin{array}{l}\text { Establishes an } \\
\text { expert' assessment } \\
\text { of a category of } \\
\text { events. }\end{array}$ \\
\hline
\end{tabular}

\section{Discussion: re-assembling social inquiry}

6.1 Assessing this range of research methods, techniques and designs from a materialist perspective suggests three features of research-assemblages and their micropolitics that bear on the concerns of this paper with social research theory and practice. First, most research-assemblages possess just the few relations and affects needed sequentially to perform simple tasks of interconnected machines. By breaking researchassemblages down into their component parts, a materialist analysis can exploit this sparseness, to reverse engineer research machines to disclose their affects and what they do, both de-mystifying the research process, and allowing research designs and methods to be manipulated to serve particular ends.

6.2 Second, generally speaking, the affective flows in most of the research assemblages and machines reviewed have in common that they produce simplicity where there was complexity, definition in place of indeterminacy, and evenness where there was variability, with consequences for the knowledge social inquiry produces. Earlier we noted (following Deleuze and Guattari) that affects come in two forms: an affect that produces a change in one (rather than multiple) relations in an assemblage are 'singular' in their effects, while 'aggregative' affects clump relations together in some way. Scrutinising Tables 1 and 2, it is striking how many research methods, techniques and designs have affective flows that aggregate event affects in one way or another. From selecting which events to study, to which features of events to subject to attention, through analytic methods that categorise or reduce data and frame it theoretically or conceptually, to reporting findings and assessing their significance, affective flows in the research-assemblage act upon the affects of the events being studied to produce research outputs that are aggregations, generalisations or summaries. From this perspective, survey and interview methodologies reveal less divergence than might have been predicted from the rival claims of their advocates.

6.3 Aggregation influences how events are presented in research reports, tending toward a loss of detail or granularity in what is been described. Whether it is through a descriptive statistic such as a mean or a confidence interval, or a thematic presentation of qualitative data, aggregations have the effect of excluding the outliers and aberrations that in social life may be extremely significant; the social world thus presented seems more bland and less exceptional than it might to those immersed within it. On occasions, the aggregative character of research is subverted, enabling singular flows within event-assemblages. Examples include case study designs 
that offer detailed descriptions of events and their contexts; analyses that seek out aberrant events or utterances rather than the 'representative' illustrations often favoured by researchers when reporting data; and studies that set out to change the world rather than simply understanding it, including emancipatory or transgressive action research that involve participants in a research setting in undertaking research themselves in order to improve some aspect of their world (Fox 2003), feminist/queer research that sets out to challenge and disrupt patriarchal and heteronormative orthodoxies (Braidotti 2013; Gillies and Alldred 2012), and 'schizoanalytic' and 'diffractive' research designs inspired by DeleuzoGuattarian and Baradian theory (Renold and Ringrose 2011; Taguchi and Palmer 2013) that aim to trouble received wisdom and produce new possibilities within the settings researched.

Third, these kinds of aggregating affect economies within research machines and assemblages (that variously corral events and their characteristics into categories, codes and themes) territorialise affects in the $E$ assemblage, shifting the micropolitics of the research-assemblage and the hybridised $R / E$ assemblage firmly toward the researcher's agenda. This is unsurprising; after all research machines have been designed to enable researchers to do research, though this assessment rejects any argument that research is in some way a 'neutral' event. A materialist analysis of the interactions between event, research process and researcher supplies a nuanced view of the micropolitics of research-assemblages: by analysing the affects in the hybrid $R / E$ assemblage, it is possible to assess in what ways, and to what extent, event affects have been territorialised (or de-territorialised) by the affect economy of the research process, and which machines and designs have done this.

One outcome of such a micropolitical analysis of research is a refinement of a strict constructionist perspective on research, which has tended to regard knowledge of the world produced by social inquiry as highly contingent upon the conditions of its production by researchers (Thibodeaux 2014: 830), or constitutive of the objects it describes. So, for instance, in the progressive territorialisations by psychological sciences of nonnormative sexualities (Alldred and Fox 2015), Rose (1998: 55) argued that 'evidence, results, arguments, laboratories, status and much else' contributed to the construction of differing 'truths' about LGBT sexualities as pathology, then deviance, then diversity. Up to a point, a materialist analysis would assent to this assessment: as has been seen, an aggregating and territorialising research-assemblage will dominate the affective flow in a hybrid $R / E$ assemblage, reshaping the $\mathrm{ABC}$ affects of the event in the research's image. However, the materialist analysis differs in two key ways.

6.6 Firstly, as was noted earlier, the ABC affects of an event cannot be entirely erased from an R/E assemblage: except in intentionally fraudulent or fictitious research reports, or where the machines in a research-assemblage are wildly inappropriate ('invalid' or 'unreliable'), something of the event's affective flow will inevitably remain in the research outputs. Pulling apart a research-assemblage to interrogate its machines and their affects can certainly disclose these flawed processes, but more generally, it can specify and evaluate precisely what aggregations and territorialisations a research-assemblage has wrought upon its subject-matter, and hence the extent to which research outputs provide useful knowledge of events.

6.7 Secondly, if disseminated into the social arena, these outputs (for example, a particular scientific understanding of non-normative sexuality) may indeed feed into the event-assemblage upon which they are based, potentially altering the latter's affective flows and what it can do - for instance, by producing guilt in people involved in a 'taboo' sexual practice. However, from an assemblage perspective, the aggregated and territorialised output of a research-assemblage is only one among the many relations that contribute to an eventassemblage, and only if the research-assemblage's affective capacity is exceptionally powerful (for example, a religious, political or scientific dogma) might an event's affect economy be fully overwhelmed. Furthermore, analysis of the affect economies within a research-assemblage can enable precise assessment of the extent to which it has re-constituted an event in its own image. Though powerful cultural forces (including scientific orthodoxies) always have the potential to influence the affect economy of a research-assemblage, social inquiry is not doomed to inevitably and uncritically recapitulate these social and cultural forces.

6.8 If this nuanced understanding of the relational micropolitics within event/research hybrid assemblages offers a different assessment of research knowledge from constructionist suggestions that social inquiry inevitably produces contingent, ideological knowledge of the events it investigates, there is also clear water between a materialist analysis of the social world (and research's capacity to reveal it) and a realist perspective. We have shown how affects in the research assemblage inevitably must interact with those in the eventassemblage if research is to be other than merely descriptive, denying the possibility of unmediated translation of an observed event into research knowledge of it (see Barad (1996) for a comprehensive critique of correspondence theories of truth). ${ }^{[7]}$ At the same time, the materialist understanding of events as relational - 
comprising affects that interact ceaselessly to produce new capacities - suggests a social ontology of flux and becoming rather than of being and stability.

While the opportunity afforded by materialist ontology to peer inside the machines and assemblages of social inquiry has permitted us to assess the research process micropolitically by unpacking its affect economy, perhaps of greater significance is the potential also to manipulate these micropolitics. We can, if we so wish, design and re-engineer research-assemblages and machines (the data collection machine, the validity machine, the analysis machine and so on) to include or exclude specified aggregative and territorialising effects, thereby innovating creative research-assemblages that produce specific capacities in researchers, data and the events studied.

6.10 Though this could be simply a charter for removing as many aggregating affects as possible from social inquiry (for instance, a sampling frame that takes uniqueness as its criterion; adopting a descriptive approach to data analysis), we would suggest there is potential for a more sophisticated response. Alongside such efforts to develop less aggregating and territorialising research-assemblages, the capacity afforded by a materialist perspective upon research to critically assess the affects that make research machines work suggests a potential rehabilitation for a range of methodologies sometimes seen (typically by naturalistic researchers) as highly territorialising: surveys, experiments and quasi-experiments. At the same time, proponents of such designs must temper their enthusiasm with an explicit commitment to review reflexively and account for the aggregations and territorialisations they produce in R/E hybrid assemblages and hence in their findings (Gillies and Alldred 2012: 57). These can be acknowledged and their impacts predicted, probabilistically if not absolutely.

6.11 This may also supply a new justification for applying a mix of methods within studies, some highly aggregative but analytically powerful, others less analytical but intentionally non- or even dis-aggregative. For instance, a study might combine a (minimally-aggregative) descriptive case study that produces a rich picture of the concerns and values of research participants in a setting with an intervention (highly aggregative) that attempts to alter aspects of the setting to address these concerns and values. A subsequent evaluation might combine aggregative quantitative measures with opportunities for participants to offer their own unmediated assessments of any improvements, and use the research outputs to challenge policy or improve their living environment. Mixing methods and methodologies in this way does not mean that the aggregations of particular methods are somehow 'cancelled out'. But because researchers can estimate precisely what aggregations their methods entail, the consequences for knowledge-production can be accurately predicted and acknowledged when reporting findings and drawing conclusions.

6.12 In this paper we have taken the precepts of new materialism and run with them, to explore what they mean for social inquiry. What then of the suggestion that new materialism resolves the contradictory perspectives on knowledge production between realism and constructionism (Coole and Frost 2010: 26-27)? It would be a neat coda to the paper to argue that our analysis has revealed a new resolution of this dualism. But we would suggest that this is not an appropriate conclusion; instead, what a new materialist perspective on social inquiry has done is to change the terms of reference for the discussion. Rather than trying to answer an anthropocentric question of belief or scepticism about the possibility of gaining knowledge of the world independent of human culture, what our analysis has done is to look at what research actually does. We have used the 'turn to matter' and a DeleuzoGuattarian materialism of assemblages and affects to disclose the micropolitical workings of the research-assemblage as it hybridises with an event-assemblage. We have thereby offered a means to assess the effects of every element of the research process on both events and on the knowledge that research produces.

6.13 Materialist analysis of research-assemblage micropolitics, we would simply conclude, supplies an innovative take on the ontology of social research that opens up possibilities for how research is designed and undertaken, what capacities the research assemblage produces in researchers, research tools, audiences and events, and how a range of methodologies and methods may be critically applied and combined in the pursuit of useful understanding of the world and human culture.

\section{Notes}

Ontology concerns propositions about the fundamental nature of things and the kinds of things that exist, while epistemology addresses how these things can be known by an observer. 
For some readers, the recognition that agency extends beyond humans will be reminiscent of the emphasis in Actor-Network Theory (ANT) upon non-human 'actants' that contribute to social production alongside human agents. This convergence between ANT and Deleuze and Guattari's materialism is also evident in Latour's (2005) understanding of the social as relational and assembled, and Law's (1992) discussion of a heterogeneous network of forces deriving from both the natural and social worlds.

Our terms 'singular' and 'aggregative' replace the somewhat obscure DeleuzoGuattarian terms 'molecular' and 'molar' that derive from physical chemistry.

The machinic analysis offers a materialist understanding both of research's design and its failings.

Research machines do not work perfectly - they break down, misfire, go into reverse or self-destruct. This can occur because of legitimate but faulty/inappropriate affects in the machine (for instance, a statistic not suited to a particular type of data, or an inexperienced or insensitive interviewer), or due to extraneous sources such as reticent or disruptive research-participants, unpredictable factors in the physical or cultural environment of a study, or unprofessional or fraudulent behaviour by researchers.

For this exercise, we exclude the subjective biases, prejudices or commitments of researchers and other 'extraneous' affects from our analysis of the research-assemblage. In practice, these will also contribute to the $R / E$ assemblage and its micropolitics.

A second level of coding may be undertaken to further reduce the variability in the data, but this again comprises just two affects: one that develops the aggregation/coding scheme, and a second that aggregates the (coded) data into an even more limited number of categories or themes. Sometimes code-generation will overlap aggregation, with codes generated 'on the hoof' as new categories emerge from the data.

Our analysis of the interactions between event- and research-assemblages is cognate with Barad's (1996) ontology of events and observers, but without recourse to quantum mechanical theory.

\section{References}

ALLDRED, P. and Fox, NJ (2015) 'From "Lesbian and Gay Psychology" to a Critical Psychology of Sexualities', in Parker, I. (ed.) Handbook of Critical Psychology. London: Routledge.

ALVESSON, M. and Skoldberg, K. (2009) Reflexive Methodology (2nd edition). London: Sage.

ANDERSON, B. (2010) 'Becoming and being hopeful: towards a theory of affect',Environment and Planning D: Society and Space, Vol. 24, No. 5, p. 733-752.

ANSELL PEARSON, K. (1999) Germinal Life. London: Routledge.

BARAD, K. (1996) 'Meeting the universe halfway: realism and social constructivism without contradiction', in Nelson, L.H. and Nelson, J. (eds.) Feminism, Science and the Philosophy of Science, p. 161-194. Dordrecht; Kluwer.

BARAD, K. (2003) 'Performativity: toward an understanding of how matter comes to matter',Signs, Vol. 28, No. 3, p. 801-831.

BEST, S. (1995) 'Sexualizing space', in Grosz, E. and Probyn, E. (eds.),Sexy Bodies, p. 181-194. London: Routledge.

BRAIDOTTI, R. (2000) 'Teratologies', in Buchanan I and Colebrook C (eds.)Deleuze and Feminist Theory, p. 156-172. Edinburgh: Edinburgh University Press.

BRAIDOTTI, R. (2006) Transpositions. Cambridge: Polity.

BRAIDOTTI, R. (2013). The Posthuman. Cambridge: Polity. 
CHEAH, P. (2010) 'Non-dialectical materialism', in Coole, D.H. and Frost, S. (eds.)New Materialisms: Ontology, Agency, and Politics, p. 70-91. Durham, NC: Duke University Press.

CLOUGH, P.T. (2004) 'Future matters: technoscience, global politics, and cultural criticism', Social Text, Vol. 22, No. 3, p. 1-23.

CLOUGH, P.T. (2008) 'The affective turn: political economy, biomedia and bodies', Theory, Culture \& Society, Vol. 25, No. 1, p. 1-22.

COLEMAN, R. and RINGROSE, J. (2013) 'Introduction', in Coleman, R. and Ringrose, J. (eds.)Deleuze and Research Methodologies, p. 1-22. Edinburgh: Edinburgh University Press.

CONNOLLY, W.E. (2011) 'The complexity of intention', Critical Inquiry, Vol. 37, No. 4, p. 791-98.

COOLE, D.H. and FROST, S. (2010) 'Introducing the new materialisms', in Coole, D.H. and Frost, S. (eds.)New Materialisms: Ontology, Agency, and Politics, Durham, NC: Duke University Press. p. 1-45.

COYNE, I.T. (1997) 'Sampling in qualitative research. Purposeful and theoretical sampling: merging or clear boundaries?' Journal of Advanced Nursing, Vol. 26, No. 3, p. 623-630.

DANERMARK, B., Ekstrom, M., Jaokobsen, L. and Karlsson, J. (2002)Explaining Society. Critical Realism in the Social Sciences. London: Routledge.

DELANDA, M. (2006) A New Philosophy of Society. London: Continuum.

DELEUZE, G. (1988) Spinoza: Practical Philosophy. San Francisco: City Lights.

DELEUZE, G. and Guattari, F. (1984) Anti-Oedipus: Capitalism and Schizophrenia. London: Athlone.

DELEUZE, G. and Guattari, F. (1988) A Thousand Plateaus, London: Athlone.

FOUCAULT, M. (1981) The History of Sexuality Vol.1: The Will to Knowledge. Harmondsworth: Pelican.

FOX, N.J. (2003) 'Practice-based evidence: towards collaborative and transgressive research',Sociology, Vol. 37, p. 81-102.

FOX, N.J. and Alldred, P. (2013) 'The sexuality-assemblage: desire, affect, anti-humanism', Sociological Review, Vol. 61, No. 4, p. 769-789.

FOX, N.J. and Alldred, P. (2014) 'New materialist social inquiry: designs, methods and the researchassemblage', International Journal of Social Research Methodology, DOI: $10.1080 / 13645579.2014 .921458$

GAME, A. (1991) Undoing the Social. Buckingham: Open University Press.

GILLIES, V. and Alldred, P. (2012) 'The ethics of intention: research as a political tool', in Miller, T., Birch, M., Mauthner, M. and Jessop, J. (eds.) Ethics in Qualitative Research, p. 43-60. London: Sage.

GROSZ, E. (1994) Volatile Bodies. Bloomington: Indiana University Press.

HARAWAY, D. (1991) Simians, Cyborgs and Women: The Reinvention of Nature. New York: Routledge.

HARAWAY, D. (1997) Modest Witness@Second_Millennium. London: Routledge.

HARMAN, G. (2013) 'Conclusions: assembly theory and its future', in Acuto, M. and Curtis, S. (eds.) Reassembling International Theory, p. 118-130. Basingstoke: Palgrave Macmillan.

JACKSON, A.Y. and Mazzei, L.A. (2013) 'Plugging one text into another: thinking with theory in qualitative research', Qualitative Inquiry, Vol. 19, No. 4, p. 261-271.

KITZINGER, C. (1987) The Social Construction of Lesbianism. London: Sage.

LATOUR, B. (2005) Reassembling the Social. Oxford: Oxford University Press.

LAU, R. and Morgan, J. (2014) 'Integrating discourse, construction and objectivity: a contemporary realist approach, Sociology, Vol. 48, No. 3, p. 573-589. 
LAW, R. (1992) 'Notes on the theory of the actor-network: ordering, strategy and heterogeneity',Systems Practice, Vol. 5, No. 4, p. 379-93.

MASSUMI, B. (1988) 'Translator's foreword and notes', in Deleuze, G. and Guattari, F. A Thousand Plateaus, p. ix-xix. London: Athlone.

MASSUMI, B. (1996) 'The autonomy of affect', in Patton, P. (ed.)Deleuze: a Critical Reader, p. 217-239. Oxford: Blackwell.

MORGAN, D.L. (2007) 'Paradigms lost and pragmatism regained', Journal of Mixed Methods Research Vol. 1, No. 1, p. 48-76.

POTTS, A. (2004) 'Deleuze on Viagra (or, what can a Viagra-body do?)',Body \& Society, Vol. 10, No. 1, p. $17-$ 36.

RENOLD, E. and Ringrose, J. (2011) 'Schizoid subjectivities? Re-theorizing teen girls? sexual cultures in an era of "sexualization" ', Journal of Sociology, Vol. 47, No. 4, p. 389-409.

RINGROSE, J. and Renold, R. (2014) ' "F**k rape!": Exploring affective intensities in a feminist research assemblage', Qualitative Inquiry, Vol 20, No. 6, p. 772-780.

ROSE, N. (1998) Inventing Our Selves: Psychology, Power, and Personhood. Cambridge: Cambridge University Press.

SHALIN, D.N. (1990) 'The impact of transcendental idealism on early German and American sociology',Current Perspectives in Social Theory, Vol. 10, No. 1, p. 1-29.

STANLEY, L. and Wise, S. (1993) Breaking Out Again (2nd Edition). London: Routledge.

TAGUCHI, H.L. and Palmer, A. (2013) 'A more 'livable' school? A diffractive analysis of the performative enactments of girls' ill-/well-being with(in) school environments', Gender and Education, Vol. 25, No. 6, p. 671-687.

TAYLOR, C.A. and Ivinson, G. (2013) 'Material feminisms: new directions for education',Gender and Education, Vol. 25, No. 6, p. 665-670.

THIBODEAUX, J. (2014) 'Three versions of constructionism and their reliance on social conditions in social problems research', Sociology, Vol. 48, No. 4, p. 829-837.

THRIFT, N. (2004) 'Intensities of feeling: towards a spatial politics of affect', Geografiska Annaler Series B Human Geography, Vol. 86, No. 1, p. 57-78.

VAN DER TUIN, I. and Dolphijn, R. (2010) 'The transversality of new materialism', Women: A Cultural Review, Vol. 21, No. 2, p. 153-171.

YOUDELL, D. and Armstrong, F. (2011) 'A politics beyond subjects: the affective choreographies and smooth spaces of schooling', Emotion, Space and Society, Vol. 4, No. 3, p. 144-150. 